\title{
Glochinema bathyperuvensis sp. n. (Nematoda, Epsilonematidae): A new species from Peruvian bathyal sediments, SE Pacific Ocean
}

\author{
Carlos Neiraa ${ }^{1, *}$, Gunnar Gad ${ }^{2}$, Nina L. Arroyo ${ }^{3}$, \& Wilfrida Decraemer ${ }^{4}$ \\ IInstitute for Chemistry and Biology of the Marine Environment (ICBM), Carl von Ossietzky University of \\ Oldenburg, Postfach 2503, D-26111 Oldenburg, Germany; 'ZZoomorphology, Faculty of Biology, Carl von \\ Ossietzky University of Oldenburg, Carl-von-Ossietzky-Str. 9-11 D-26111 Oldenburg, Germany; \\ ${ }^{3}$ Department of Zoology, Faculty of Biology, University of Complutense, 28040 Madrid, Spain; ${ }^{4}$ Koninklijk \\ Belgisch Instituut voor Natuurwetenschappen Section of Recent Invertebrates, Vautierstraat 29 B-1000 \\ Brussels, Belgium
}

Key words: Glochinema bathyperuvensis sp. n., Nematoda, Epsilonematidae, bathyal sediments, oxygen minimum zone, El Niño, Peru

\begin{abstract}
Glochinema bathyperuvensis sp. $\mathrm{n}$, the first record of Epsilonematidae from bathyal muddy sediments of the oxygen minimum zone (OMZ) off Callao, Peru (eastern Pacific Ocean) is described. The new species belongs to the subfamily Glochinematinae and is characterized by the possession of more than 8 pairs of subdorsal thorns asymmetrically arranged and a single dorsal one in the pharyngeal region, as well as by the presence of ten to thirteen blade-like cuticular protrusions forming a latero-dorsal palisade around the posterior head region and anterior cervical region. In addition, $G$. bathyperuvensis is characterized by its large size, more than 240 cuticular annules, provided with an extremely dense, ,hairy" body ornamentation and, four rows of ambulatory setae: two inner subventral ones with 8 to 9 setae in males, and 5 to 6 setae in females, and two outer subventral rows composed each of 9-12 ambulatory setae followed by a large number of modified somatic setae. The dense hairy body spines, the large number of modified somatic setae, its dominant occurrence exclusive in oxygen-depleted, organicrich soupy surface sediments indicate an adaptation to the stressed OMZ habitat conditions.
\end{abstract}

\section{Contents}

$\begin{array}{ll}\text { Abstract } & 147 \\ \text { Introduction } & 147 \\ \text { Material and Methods } & 148 \\ \text { Systematic description } & 148 \\ \quad \text { Diagnosis } & 148 \\ \text { Remarks } & 152 \\ \text { Discussion } & 152 \\ \quad \text { Taxonomic relationships } & 152\end{array}$

Ecological considerations $\quad 152$

Acknowledgements $\quad 158$

Referençes

\section{Introduction}

Epsilonematidae is a well defined family of Nematoda currently comprising thirteen genera and eighty-one species distributed in three subfamilies (Epsilonematinae, Keratonematinae and Glochinematinae). Hitherto, all representatives of Epsilonematidae have been found worldwide in supralittoral or intertidal sandy shores (Gourbault \& Decraemer 1996).

In the last years, considerable attention has been focused on the study of the benthic communities living within oxygen minimum zones (OMZs, oxygen concentrations $<0.5 \mathrm{ml} \mathrm{l}^{-1}$ ) (Kamykowski \& Zentara 1990; Levin et al., 1991). These OMZs are well developed along the eastern Pacific Ocean (Wyrtki 1966; Kamykowski \& Zentara 1990) where high productivity associated to upwellings and poor water circulation occur. Where OMZs impinge on the continental margin, strong gradients are formed in bottom-water oxygen and organic matter input (Levin et al., 1991; Levin et al., 2000). These influence biogeochemical properties of sediments and benthic fauna distributions (Sanders 1969; Tyson \& Pearson 1991).

\footnotetext{
*Programa FONDAP-Humboldt, Conicyt, Santiago, Chile. Address for correspondence: C. Neirra, Marine Life Research Group,
} Scripps Institution of Oceanography, La Jolla, CA 92093-0218, USA, fax no.x +1 858822 0562, E-mail: cneira@coast.ucsd.edu 
Examination of bathyal sediment samples obtained during the cruise Panorama Leg 3a along a transect through and beneath the OMZ off Peru, resulted in the discovery of a new species of the genus Glochinema (Glochinematinae). In this paper, we describe this new nematode species, which was found exclusively in the core of the $\mathrm{OMZ}\left(\mathrm{O}_{2}\right.$ $<0.02 \mathrm{ml} \mathrm{l}^{-1}$ ). This represents the first record of the family from Pacific Ocean continental slope sediments.

\section{Material and methods}

The study area is one of the most productive (over $1000 \mathrm{~g} \mathrm{C}$ $\mathrm{m}^{-2} \mathrm{y}^{-1}$ ) eastern boundary systems in the world (Walsh 1981; Arntz et al, 1991). This high productivity results from intense and persistent wind-driven coastal upwelling. The Humboldt Current System (HCS) exhibits here a thin but intense midwater oxygen minimum layer, generally associated with the equatorial subsurface water mass (Morales et al. 1996). The Peru margin samples were collected during the R/V Melville Cruise "PANORAMA Leg 3a" (December 31, 1997 to January 3, 1998) from a 305-m site (Station A, 12 22.70's; $77^{\circ} 29.07^{\prime} \mathrm{W}$ ), using a multiple corer. The sampling occurred concurrently with the 1997-98 El Niño, when surface temperature anomalies off Callao were at their maximum (G. Sanchez, pers. comm.). Environmental data for the study site are summarized in Table 1. Further details of the cruise and the other sites are reported elsewhere by Neira et al. (in press).

Sediment core were cut vertically at $0-1,1-2,2-3,3-5$, and 5-10 $\mathrm{cm}$ and treated with a solution of magnesium chloride, and preserved in $10 \%$ buffered formalin containing Rose Ben-

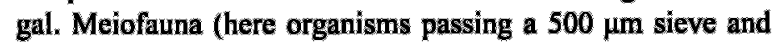
retained on a $40 \mu \mathrm{m}$ sieve) were separated by the suspensiondecantation method (Wieser, 1960) with a few modifications (Neira \& Rackemann, 1996). Nematodes were mounted in anhydrous glycerine. Measurements and drawings were mpde using a Leica (DMLB 100T) intereference contrast microscope. SEM of nematodes involved dehydration with ethanol, subsequent critical-point drying, and coating with $\mathrm{Au}$. Specimens were examined with a Zeiss DSM 940. Type material deposited in the nematode collections of the Alfred Wegener Institute (AWI), Bremerhaven, Germany and one male (RIT 663) and one female (RIT 664) in the Nematode collection of the Koninklijk Belgisch Instituut voor Natuurwetenschappen, Brussels (KBIN).

\section{Systematic description}

Family Epsilonematidae Steiner, 1927

Subfamily Glochinematinae Lorenzen, 1974

Glochinema Lorenzen, 1974

\section{Glochinema bathyperuvensis $\mathrm{sp}, \mathrm{n}$.}

(Measurements in Table 2.)

Type material. Holotype male or 1, mounted on slide $573 \mathrm{Ho}$ and Allotype female $\$ 2$ on slide $573 \mathrm{~A}$ \% $\mathrm{E}$; paratype $\sigma^{*} 1$ on slide $573 \mathrm{Po}$; other paratypes specimens on slide $573 \mathrm{P2}$ o $\%$, $573 \mathrm{P3} \sigma^{*} \%, 573 \mathrm{P} 4 \sigma^{\circ} \%$, and 1 juvenile on slide 573 P5 Juv (AWI). Also, 1 male $\sigma^{\prime}$ on slide RIT 663,1 female $q$ on slide RIT 664 (KBIN).

Type locality. Continental slope (305 $\mathrm{m}$ depth) off Callao, Peru (12 22.70S; $\left.77^{\circ} 29.07^{\circ} \mathrm{W}\right)$, Jan. 1, 1998.

Habitat. Marine, bathyal, $\mathrm{O}_{2}$-depleted bottom-water; organic carbon-rich muddy sediment, mainly at the upper sediment layers. Relative dominance from nematodes: $21 \%$ (top $1 \mathrm{~cm}$ ).

Etymology. The specific name refers to the bathyal depth and to the Peru margin.

Diagnosis. - Specimens of large size (1040-1335 $\mu \mathrm{m})$, with more than 240 cuticular annules. More than 8 pairs of subdorsal thorns asymmetrically arranged and one dorsal thorn present in pharyngeal region together with ten to thirteen blade-like cuticular protrusions forming a latero-dorsal palisade around the posterior head region and anterior cervical region. Body strongly ornamented with a dense cover of hairy spines and some stronger spines of different size. Ambulatory setae in 4 rows: two inner subventral rows with 8 to 9 in males and 5 to 6 setae in female (one or two behind the vulva), and two outer subventral rows with 9-12 long ambulatory setae up to the end of the swollen midpart, followed by $20-27$ nearly straight supporting setae.

\section{Male}

Body large, epsilon-shaped, anterior region very elongated and slender to ventral bend with sharp concave-dorsal curvature at the anterior cervical region and, mid-body ventrally plicated with a noticeable enlargement at testis level reaching its maximum body diameter $(110 \mu \mathrm{m})$ (Fig.1A). Thick body cuticle distinctly annulated; annules overlapping by a well-developed hyaline outer-layer, changing in direction ventrally at level of annules 93108 , depending on the specimens. Dorsal inversion is less apparent, taking place 5-10 annules posterior to the ventral inversion. Anteriormost annules devoided of hairy spines. From annule 13 
onward in holotype, annules ornamented with faint transversal ridges and hairy spines. The latter becoming more numerous in the enlarged mid-body portion where intermingled with stronger spines. Immediately posterior to the base of the pharynx, 7-8 anteriorly oriented thorns, located ventrally between annules 48 and 59 (Fig. 3A), coinciding with the minimum body width $(20 \mu \mathrm{m})$. Posterior to the ventral thorns, a series of thick small spines protrudes forwards from the ventral side. Nine large paired subdorsal thorns (Fig. 2A) arranged asymmetrically and a single dorsal one present in the neck region; posteriormost dorsal thorn strong. Close to the cephalic region, thorns with a more pronounced inclination towards the body, some of them accompanied by somatic setae. Also, a subventral series of ten to thirteen single blade-like cuticular protrusions forming a latero-dorsal palisade surrounding the cervical region (Fig. 4A); the two anteriormost protrusions on partial rings in posterior head region (Figs. 2A; 4B).

Ambulatory setae arranged in 4 rows: two inner subventral ones with $8-9$ straight slender setae, and two outer subventral rows with 9 long, curved (not knicked) ambulatory setae (Fig. 4E), followed by a row of 29 straight supporting setae with pointed at tip.

Head round-shaped in optical section, with a strongly cuticularized helmet (Fig. 2E), 1.5 fold narrower than the body diameter at base of pharynx. Amphids spiral, ventrally wound, medium sized $(6-7 \mu \mathrm{m})$, located in posterior head region (Figs. 2D, 4A). Head on both sides showing an indentation anterior to the amphideal fovea (Figs. 2C, 4B). Anterior sensorial organs with six inner labial papillae, six short, outer labial setae (Figs. 2C, 4C) and four cephalic setae at the level of the anterior border of the amphids (Fig. 2D). Buccal cavity narrow, with one dorsal denticle (Fig. 2E). Pharynx swollen in cephalic region, then long cylindrical, gradually enlarging to an elongated bulb with sclerotized lumen wall. Cardia short, rounded. Intestine largely dorsal of reproductive system. Intestinal cells granular with differentiated pale zone along the lumen (Fig. 1A).

Tail with 18 annules in the holotype and conico-* cylindrical end-ring, ending in a small spinneret
(Fig. 3C). Caudal glands extending far anteriorly beyond the cloacal opening.

Reproductive system, monorchic with outstretched testis reaching the anterior ventral curvature; large sperm cells; vas deferens with small granules. Spicules paired, slender, sickle-shaped, with a knob-like capitulum (Figs. 1A; 3C). Gubernaculum thin, $25 \%$ of the spicule lenght (measured along arc). A row of about 10 anal setae present on each side of the cloacal region. Annules in cloacal region ventrally to subventrally with few hairy spines (Fig. 4F). Dorsally, spines stiffened and together arranged comb-like. Some of them bifurcated at the tip.

\section{Female}

Very similar to male in habitus and cuticular ornamention. As in male, position and number of pharyngeal thorns and blade-like protrusions vary according to the specimen (Fig. 2F). Anterior sensorial organs and amphids as in male. Four rows of ambulatory setae: the inner subventral ones with 5-6 setae, one or two being posterior to vulva (Fig. 1B), and two outer subventral rows with 8 ambulatory setae, followed by about 24 supporting setae. Reproductive system didelphic-amphidelphic, with reflexed ovaries. Vulva situated ventrally at $60 \%$ of the total body length from anterior end. Vagina with short $(3 \mu \mathrm{m})$ sclerotized distal part and larger $(11 \mu \mathrm{m})$ but less sclerotized proximal part. Area surrounding the vulva devoid of ornamentation (Fig. 3D). Anterior part of the tail, slightly thinner than by males (Fig. 3E).

Juveniles. Stages 1, 2 and 3 unknown.

Fourth stage. Habitus as in adults but epsylon-shape less apparent. Body with similar number of annules (268). Anterior sensorial organs and amphid as in adult. Similar number of thorns and blade-like protrusions. However, body and tail length, as well as head and maximum body diameter clearly smaller than adults. Reproductive system not yet completely developed. Tail similar to adults both in length and number of annules. As in adults, four rows of ambulatory setae: the inner subventral ones with 5 setae, and the outer subventral row with 4 am- 


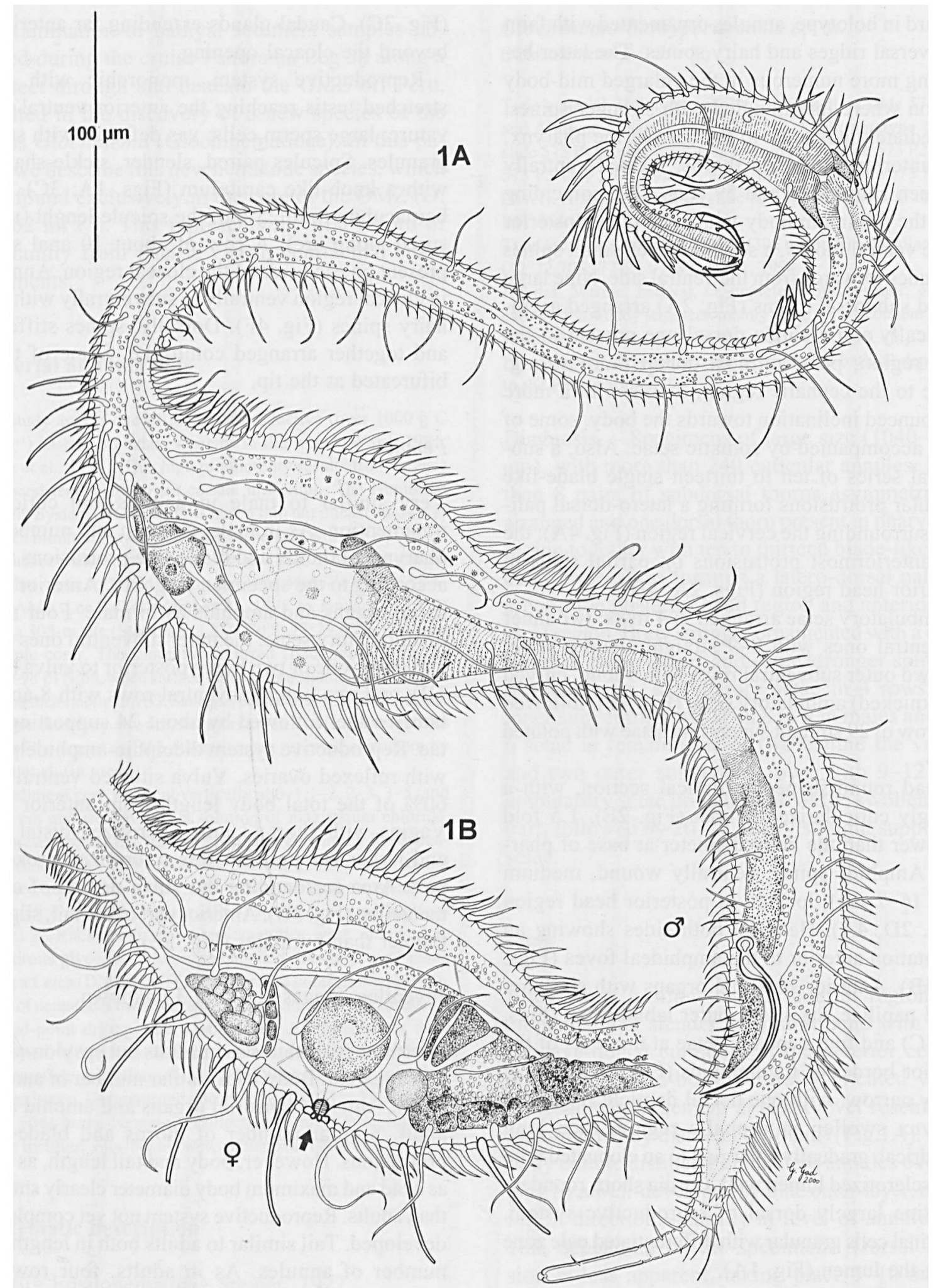

Fig. 1. Glochinema bathypertuensis sp. n. A. Habitus, male 1 (holotype). B. Mid-body region with female reproductive system; arrow shows the position of the vulva. 

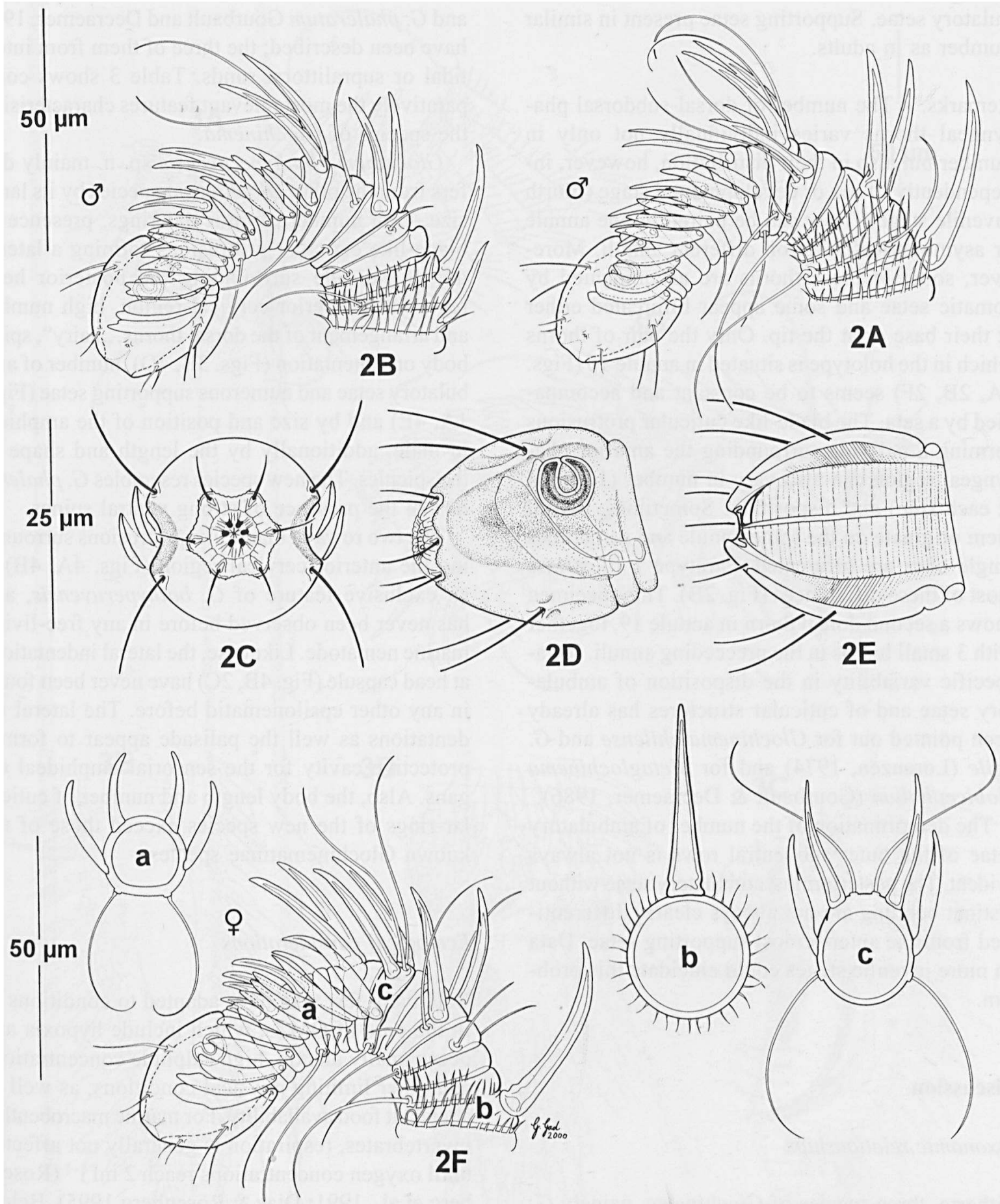

Fig. 2. Glochinema bathyperuvensis sp. n. A - B. Anterior body region in surface view showing the dorsal-subdorsal asymmetrically arranged thorns and blade-like protrusions in male 1 (holotype) and male (paratype 1), respectively. C. Front view of the head showing lateral indentations, and labial and cephalic sensorial papillae and setae. D. Head in lateral view showing amphideal fovea and the two anteriormost blade-like protrusions (dotted area indicates indentation). E. Anterior portion of the pharynx and buccal cavity with dorsal denticle; connection of the pharynx with cephalic capsule is indicated by the fibrous structures. F. Anterior body region of female 2 (allotype) showing distribution of thorns and blade-like protrusions; $a, b$, and $c$, show distribution of thorns and accompanig setae at different transverse sections as indicated in $2 \mathrm{~F}$. 
bulatory setae. Supporting setae present in similar number as in adults.

Remarks. - The number of dorsal-subdorsal pharyngeal thorns varies individually not only in number but also in their distribution, however, independently of sex or developmental stage (fourth juvenile stage). They can be paired in one annule or asymmetrically set on different annuli. Moreover, some of these thorns are accompanied by somatic setae and some appear bifurcated either at their base or at the tip. Only the pair of thorns which in the holotype is situated in annule 10 (Figs. $2 \mathrm{~A}, 2 \mathrm{~B}, 2 \mathrm{~F}$ ) seems to be constant and accompanied by a seta. The blade-like cuticular protrusions forming a palisade surrounding the anterior pharyngeal region can also vary in number (10 to 13 at each side) and disposition. Sometimes, two of them originate on the same annule and sometimes single ones are bifurcated. Paratype 1 illustrates most of these differences (Fig. 2B). This specimen shows a second dorsal thorn in annule 19 , together with 3 small lumps in the preceeding annuli. Intraspecific variability in the disposition of ambulatory setae and of cuticular structures has already been pointed out for Glochinema chilense and $G$. agile (Lorenzen, 1974) and for Metaglochinema globicephalum (Gourbault \& Decraemer, 1986).

The determination of the number of ambulatory setae of the outer subventral rows is not always evident. The posteriormost ambulatory setae without distinct bending are not always clearly differentiated from the anteriormost supporting setae. Data on more juvenile stages could elucidate this problem.

\section{Discussion}

\section{Taxonomic relationships}

Hitherto, three species of Glochinema, namely $G$. chilense Lorenzen, 1974, G. agile Lorenzen, 1974 and G. phaleratum Gourbault and Decraemer, 1993 have been described; the three of them from intertidal or supralittoral sands. Table 3 shows comparatively the most relevant features characterising the species of Glochinema.

Glochinema bathyperuvensis sp. n. mainly differs from the other Glochinema species by its large size, high number of cuticular rings, presence of blade-like cuticular protrusions forming a laterodorsal palisade surrounding the posterior head region and anterior cervical region, high number and arrangement of the dorsal thorns, ,hairy", spiny body ornamentation (Figs. 3B, 4D), number of ambulatory setae and numerous supporting setae (Figs. $1 \mathrm{~A}, 4 \mathrm{E})$ and by size and position of the amphids; in male, additionally by the length and shape of the spicules. The new species resembles G. phaleratum in the presence of strong ventral spines.

The two rows of blade-like protrusions surrounding the anterior cervical region (Figs. 4A, 4B) is an exclusive feature of $G$. bathyperuvensis, and has never been observed before in any free-living marine nematode. Likewise, the lateral indentations at head capsule (Fig. 4B, 2C) have never been found in any other epsilonematid before. The lateral indentations as well the palisade appear to form a protective cavity for the sensorial amphideal organs. Also, the body length and number of cuticular rings of the new species exceed those of the known Glochínematinae species.

\section{Ecological considerations}

Relatively few taxa have adapted to conditions as in the core of OMZs, which include hypoxia and occasionally anoxia, high sulphíde concentrations and other limiting physical conditions, as well as abundant food availlability. For marine macrobenthic invertebrates, respiration is generally not affected until oxygen concentrations reach $2 \mathrm{ml} \mathrm{l}^{-1}$ (Rosenberg et al., 1991; Diaz \& Rosenberg 1995). Below these levels, benthic invertebrates show a graded

Fig.3. Glochinema bathyperuvensis sp. n. A. Anteriorly oriented ventral thorns located immediately posterior to the base of the pharynx. Note supporting setae. B. Detail of "hairy", spiny body ornamentation. C. Male 1 (holotype), tail and reproductive system showing spicule, gubernaculum, and knob-like capitulum. D. Female 2 (allotype), arrow indicates position of the vulva and detail of the vagina. $E_{x}$ Tail and anal region of female 2 (allotype). 

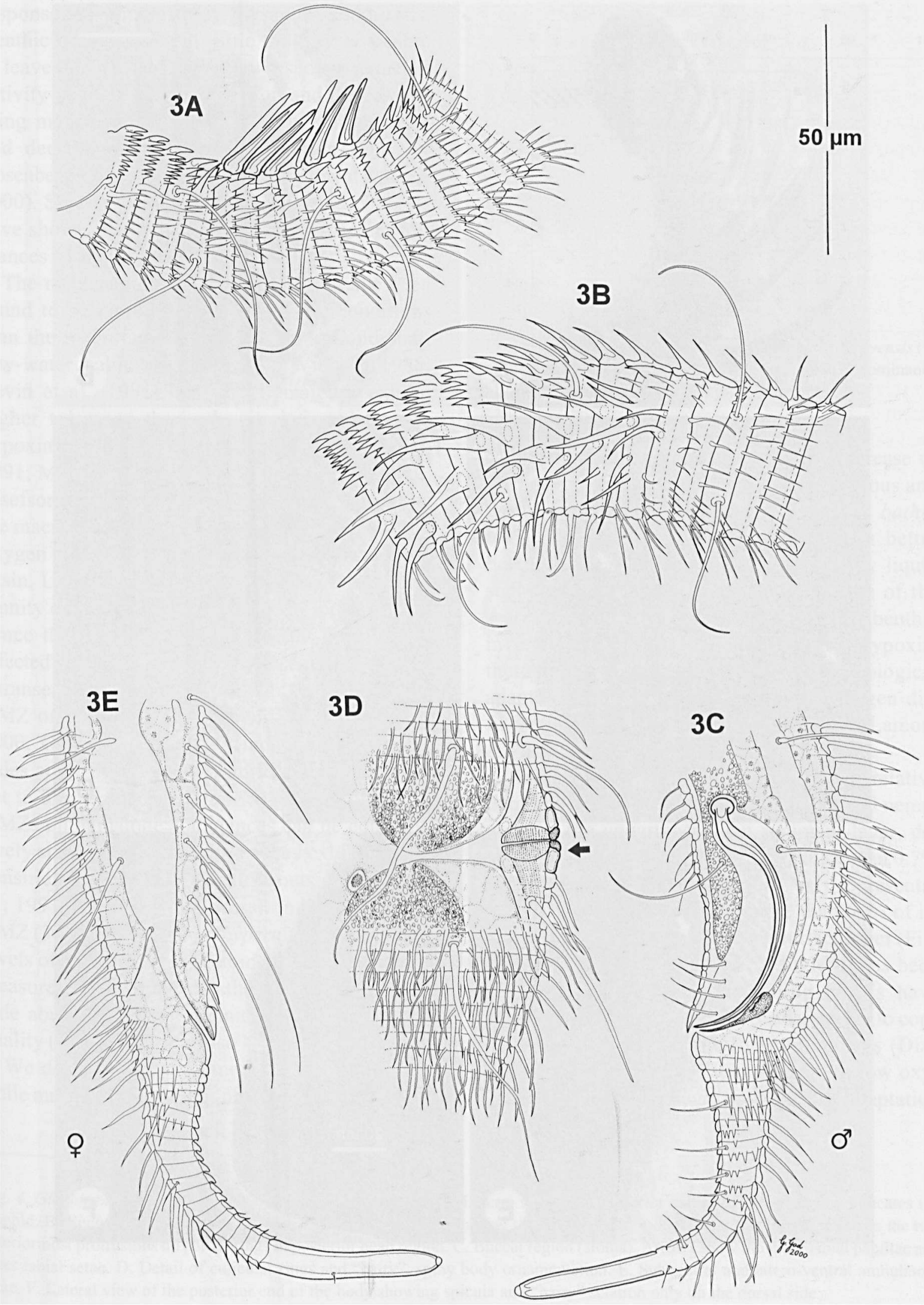

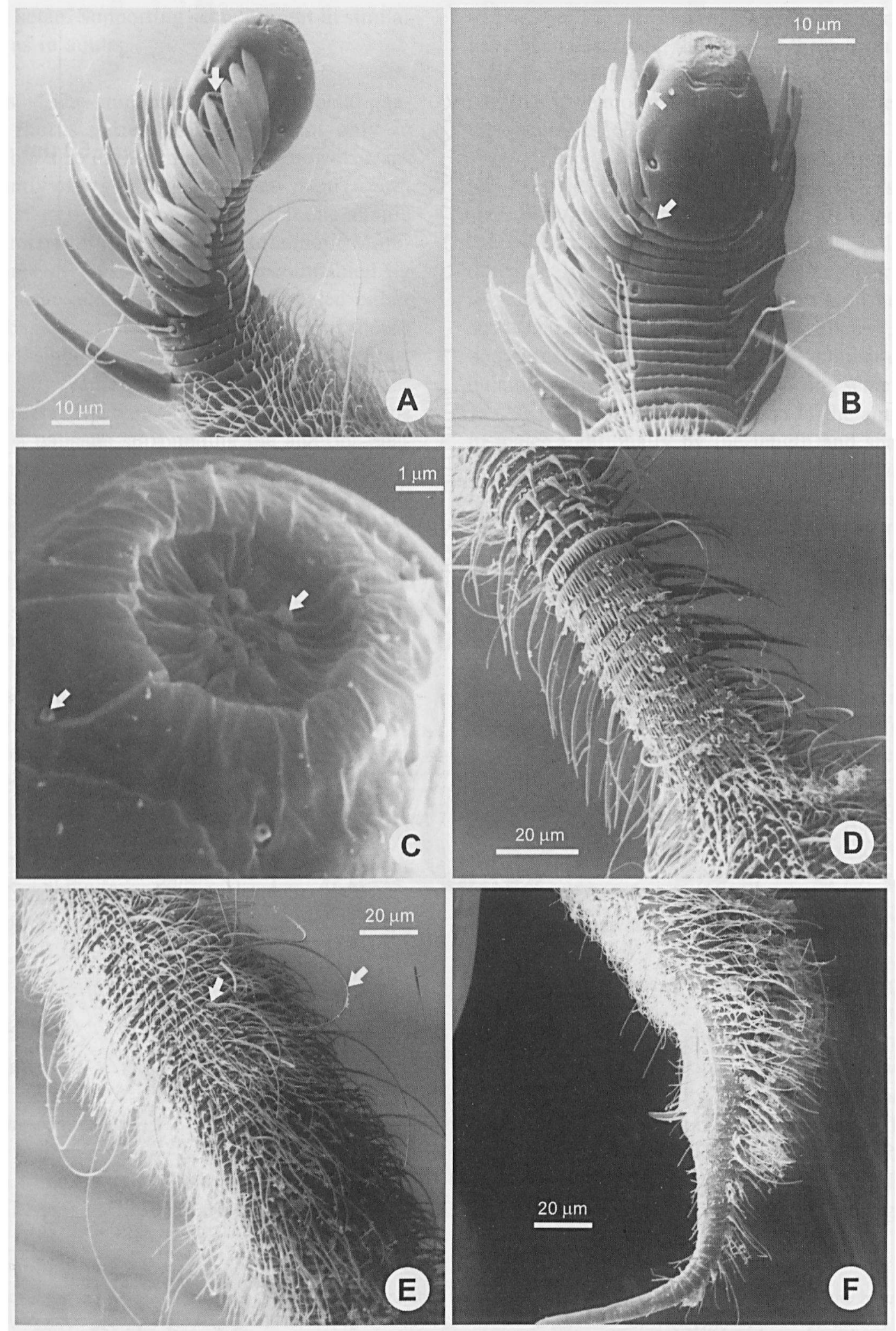
response to increasingly hypoxic conditions. Benthic organisms, with little motility or unable to leave the affected area, may response reducing activity not related to respiration and hence lowering metabolism, increasing body surface area, and decreasing depth of distribution (Diaz \& Rosenberg 1995; Levin et al., 2000; Lamont \& Gage 2000). Studies on deep and shallow environments have shown that different taxa have different tolerances to hypoxia.

The metazoan meiofauna in general have been found to be more tolerant to hypoxic conditions than the macrofauna, both in deep-sea and shallow-water habitats (Josefson \& Widbom 1988; Levin et al., 1991), and that nematodes exhibit higher tolerance than other meiofaunal taxa to hypoxia even to periods of anoxia (Levin et al., 1991; Moodley et al., 1997; Gooday et al., 2000). Josefson \& Widbom (1988) reported that unlike the macrofauna, nematodes were unaffected when oxygen dropped to $0.2 \mathrm{ml}^{-1}$ in the Gullmar Fjord basin. Levin et al. (1991) studying an OMZ community on a seamount off Acapulco found no evidence that low oxygen (range $0.09-2.60 \mathrm{ml} \mathrm{l}^{-1}$ ) affected nematode abundances. Recent studies along a transect (400-3400 m) through and beneath the $\mathrm{OMZ}$ off Oman in the Arabian Sea (Cook et al., 2000; Gooday et al., 2000) indicated that nematodes and calcareous foraminifera are most tolerant to low oxygen $\left(0.13 \mathrm{ml} \mathrm{l}^{-1}\right)$. The influence of OMZs on nematode abundances can be comparatively small, and in some cases they exhibit higher densities within the OMZs than outside (Levin et al., 1991; Neira et al., in press). In the core of the OMZ (305 m), where G. bathyperuvensis was found, levels of $0.013 \mathrm{ml} \mathrm{l}^{-1}$ of bottom-water oxygen were measured, coinciding with the highest total nematode abundances and organic matter content and quality (see Table 1 and also Neira et al., in press).

We do not know if the nematodes on the PeruChile margin OMZ possess physiological/biochemi-

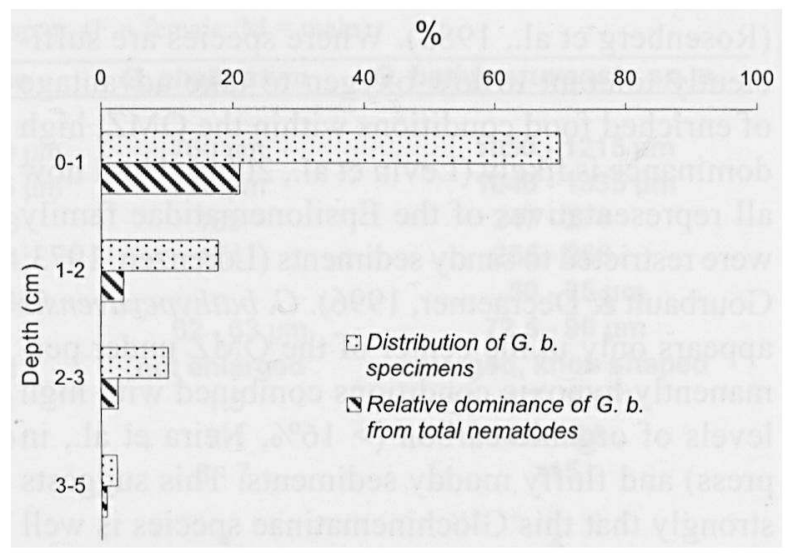

Fig. 5. Vertical distribution of Glochinema bathyperuvensis (\% of total $G$. bathyperuvensis specimens) and relative dominance of $G$. bythyperuvensis (\% from total nematodes).

cal adaptations to hypoxia. However, increase of the body surface area through dense setacious and thorny cuticular body ornamentation by G. bathyperuvensis may contribute not only to a better balance and avoid sinking in a practically liquid sediment but also to a more effective use of the scarce available oxygen $\left(<0.02 \mathrm{ml} \mathrm{l}^{-1}\right)$. For benthic invertebrates able to tolerate permanent hypoxia, there are powerful constraints for morphological adaptation aimed towards enhancing oxygen diffusion by increasing body area/mass ratio (Lamont \& Gage 2000).

Glochinema bathyperuvensis reached a relative numerical dominance of $21 \%$ from the total nematodes at the uppermost $1-\mathrm{cm}$ sediment layer, decreasing abruptly to less than $3.5 \%$ at $2 \mathrm{~cm}$ an $0.7 \%$ at $5 \mathrm{~cm}$ depth (Fig. 5). Regarding only representatives of $G$. bathyperuvensis, more than $69 \%$ of its individuals were restricted to the surface layer (Fig. 5) suggesting an epibionthic lifestyle. It has been postulated that species inhabiting OMZs have evolved energetically expensive adaptations to cope with life in oxygen-depleted environments (Diaz \& Rosenberg 1995). A fauna tolerant to low oxygen may evolve through evolutionary adaptation

\section{$\leftarrow$}

Fig. 4. Glochinema bathyperuvensis sp. n. SEM micrographs. A. Lateral view of the anterior end of the body. Arrow indicates the amphid. B. Ventral view of the head and cervical region. Superior arrow shows the lateral indentation; inferior arrow shows the two anteriormost protrusions on partial rings in posterior head region. C. Buccal region (stoma). Arrows show the inner labial papillae and outer labial setae. D. Detail of cuticular rings and "hairy", spiny body ornamentation. E. Subventral and latero-ventral ambulatory setae. F. Lateral view of the posterior end of the body showing spicula and "hairy" setation only on the dorsal side. 
(Rosenberg et al., 1983). Where species are sufficiently tolerant to low-oxygen to take advantage of enriched food conditions within the OMZ, high dominance is likely (Levin et al., 2000). Until now all representatives of the Epsilonematidae family were restricted to sandy sediments (Lorenzen, 1973; Gourbault \& Decraemer, 1996). G. bathyperuvensis appears only in the center of the OMZ under permanently hypoxic conditions combined with high levels of organic carbon ( $>16 \%$, Neira et al., in press) and fluffy muddy sediments. This suggests strongly that this Glochinematinae species is well adapted to life in environments, such as those found on the Peru margin. The high fluidity and instability of these sediments appear not to be an obstacle for G. bathyperuvensis to thrive there. Because of the high sediment organic carbon, G. bathyperuvensis probably do not need to make large movements to find its food. Instead, they may "swim" in the soupy sediment and may rely on passive transport by external processes such as periodic resuspension of the loose sediment. The special morphological features of G. bathyperuvensis are interpreted as effective adaptations to this habitat: (1) large body: living in mud does not require a small size body
Table 1. Environmental data for the oxygen minimum zone study site, summarized from Neira et al. (in press). $\mathrm{Eh}=$ redox potential; TOC $=$ total organic carbon; $\mathrm{CPE}=$ chloroplastic pigment equivalents; $\mathrm{BPC}=$ biopolymeric organic carbon (as the sum of carbohydrate, lipid and protein carbon).

\begin{tabular}{|c|c|}
\hline Property & Study site \\
\hline Depth (m) & 305 \\
\hline \multicolumn{2}{|l|}{ Bottom water } \\
\hline - Temperature $\left({ }^{\circ} \mathrm{C}\right)$ & 10.15 \\
\hline - Oxygen (ml $\left.1^{-1}\right)$ & 0.013 \\
\hline - Salinity (psu) & 34.73 \\
\hline \multicolumn{2}{|l|}{ Sediment $(0-1 \mathrm{~cm})$} \\
\hline - Porosity (\%) & 95.4 \\
\hline - Water content (\%) & 83.3 \\
\hline$-\mathrm{Eh}(\mathrm{mV})$ & 210 \\
\hline$-\operatorname{TOC}(\%)$ & 16.9 \\
\hline$-\mathrm{C}: \mathrm{N}$ ratio & 10.2 \\
\hline$-\mathrm{CPE}\left(\mu \mathrm{g} \mathrm{g}^{-1}\right)$ & 99.4 \\
\hline$-\mathrm{BPC}\left(\mathrm{mg} \mathrm{g}^{-1}\right)$ & 36.9 \\
\hline - BPC/TOC (\%) & 21.8 \\
\hline
\end{tabular}

to thrive in this milieu, (2) body ornamentation: dense spiny cuticular body ornamentation as well as long outer subventral ambulatory setae (no longer used for ambulatory supporting movements) are interpreted as an enlargement of the body surface

Table 2. Mcasurements of specimens of Glochinema bathyperuvensis sp. $\mathrm{n}$. from bathyal Peruvian margin. (dimensions in $\mu \mathrm{m}$ ).

\begin{tabular}{|c|c|c|c|c|}
\hline Measurements & Holotype & males & females & Juvenile IV \\
\hline Total body length & 1080 & $1050-1215$ & $1040-1335$ & 925 \\
\hline Number of annules & 247 & $247-265$ & $246-268$ & 268 \\
\hline Maximum body diameter: mbd & 110 & $75-110$ & $92.5-115$ & 68.8 \\
\hline Minimum body dlameter: (mbd) & 20 & 20 & 20 & 20 \\
\hline $\mathrm{mbd} /(\mathrm{mbd})$ & 5.5 & $3.8-5.5$ & $4.6-5.8$ & 3.9 \\
\hline Tail length & 132.5 & $112.5-145$ & $110-132.5$ & 105 \\
\hline Head diameter & 25 & $22.5-25$ & $23.8-27.5$ & 19.5 \\
\hline Dlameter amphideal fovea & 7 & $6-7$ & $6.5-7$ & 6.5 \\
\hline Distance from anterior to amphideal fovea & 17.5 & $14.5-17.5$ & $13-18$ & 13.5 \\
\hline Pharynx length & 200 & $162.5-220$ & $155-178.8$ & 140 \\
\hline Body diameter at pharyn $x$ basis & 35 & $31.3-35$ & $33.8-35$ & 36.3 \\
\hline Body diameter at anus level & 32.5 & $27.5-35$ & $25-26.3$ & 25 \\
\hline Spicule length by chord & 67.5 & $50-75$ & & \\
\hline Splcule length along arc & 90 & $72.5=95$ & & \\
\hline Gubernaculum & 26.3 & $17.5-26.3$ & & \\
\hline$\%$ of non-annuled tail of total tail length & 38.7 & $31.9-\overline{47.8}$ & $33-39.1$ & 38.1 \\
\hline Length of dorsal pharyngeal Thorn (LdT) & 43.8 & $26.3-43.8$ & $31.3-37.5$ & 27.5 \\
\hline Diameter at basis of dorsal pharyngeal Thorn (DdT) & 6.3 & $5-7.5$ & $5-6.3$ & 3.8 \\
\hline $\begin{array}{l}\text { Position of vulva (V) as \% of total body lenght from anterior end } \\
\text { Coefficients of de Man: }\end{array}$ & & & -60 & \\
\hline a: Body length/Body width & 9.8 & $9.8-14$ & $10.5=13$ & 13.4 \\
\hline b: Body length/Pharynx length & 5.4 & $4.8-6.9$ & $5.4-7.5$ & 6.6 \\
\hline c: Body length/Tail length & 8.2 & $8.2-9.7$ & $8.4-10.7$ & 8.8 \\
\hline & & $n=10$ & $n=10$ & $n=1$ \\
\hline
\end{tabular}


Table 3. Comparison of Glochinema species and G. bathypenivensis sp. $\mathrm{n}$. ( $\mathrm{F}=$ female; $\mathrm{M}=$ male).

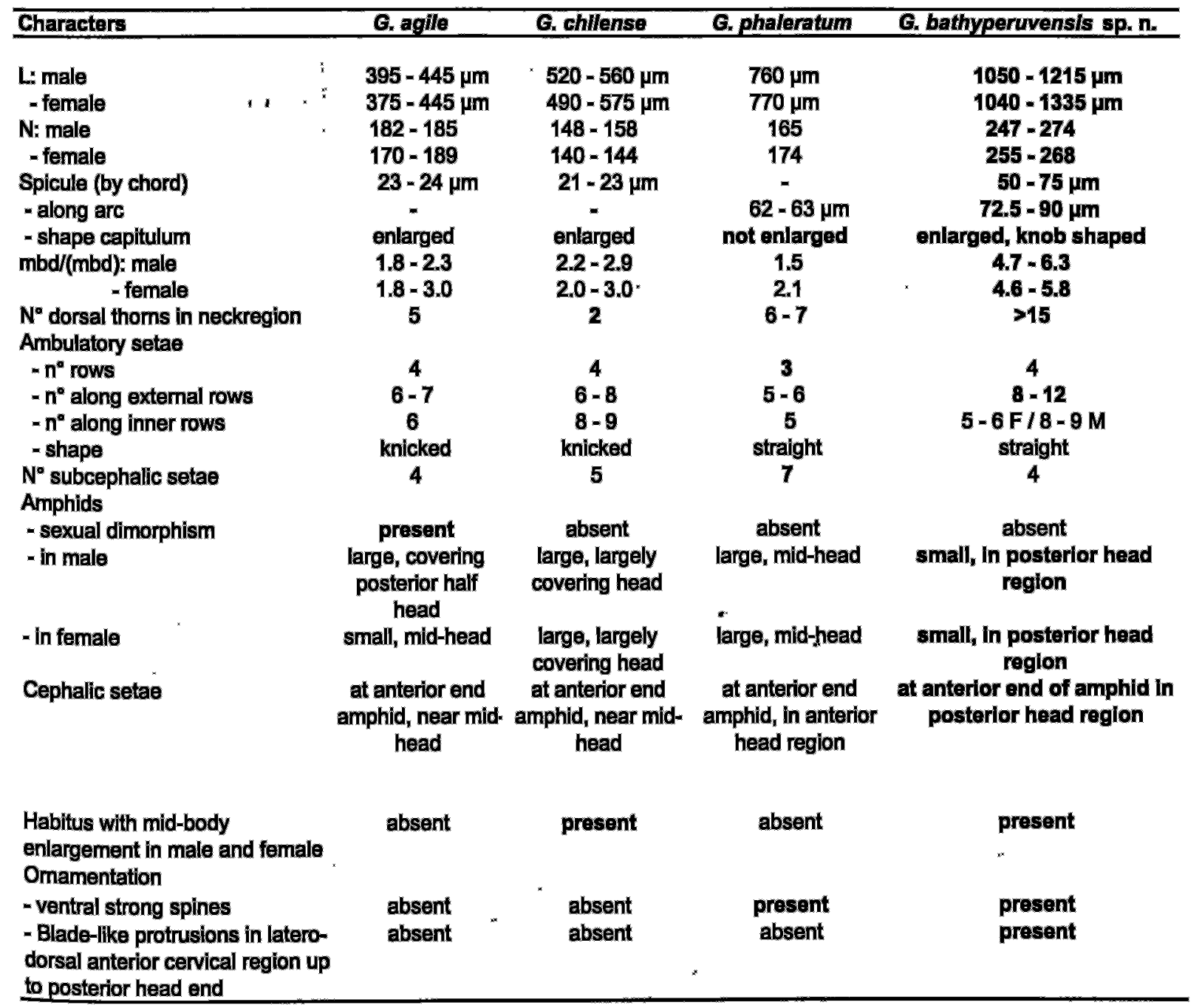

area for "swimming" and for balance in the uppermost soupy mud layers.

Further, the well muscularized pharynx, swollen in the head region and with an elongated posterior bulb suggests that the anterior digestive system is a strong suction apparatus, which may be an additional effective adaptation to cope with soupy, organic-rich sediments, which characterize the core of OMZ. This apparently expensive life form, could be compensated by the abundant food available of relative high quality (Neira et al., in press). Recently, Bernhard et al. (2000) reported the occurrence in the OMZ of the Santa Barbara Basin ( $475 \mathrm{~m}$ depth, bottom water $\mathrm{O}_{2}<0.02 \mathrm{ml}$ $\mathrm{I}^{-1}$ ) of the nematode Desmodora masira (and other eukariotic animals) which harbour prokariotic symbionts. The bacteria were aligned under the nematode's annulate cuticle. The ultrastructure point toward sulphide-oxidizing bacteria (Bernhard et al., 2000) whìch may be seen as a barrier against the toxic sulphide. Our observations did not reveal the presence of ectosymbionts on G. bathyperuvensis.

Whether there was an effect of the 1997-98 El Niño on $G$. bathyperuvensis distribution remains unknown. We speculate that El Niño might have caused a deepening in the vertical distribution of the otherwise only at the interface. Increased oxygenation of the otherwise quasi-anaerobic seafloor, increased bioturbation mainly by burrowing oligochaetes (Levin et al., unpublished), and decreased organic matter quality (Neira et al. in press) due 
to a reduced primary production (Tarazona et al., 1996) could have been the most likely causes of an increased penetration of $G$. bathyperuvensis in the sediment.

The finding of Glochinema bathyperuvensis in slope depths expands the range of known habitats for this family, i.e. from sandy intertidal sediments to muddy slope sediments. Further, considering that the bathyal regions are poorly investigated, it could indicate that the number of epsilonematid species living in the bathyal regions may be much larger than actually known.

\section{Acknowledgements}

We are grateful to Dr. F. Riemann for stimulating discussions and his kind help with literature and nematode identifications. We are sincerely thankful to Dr. P. Martinez for interesting discussions and technical "tips" in the laboratory. We wish to thank Drs L. Levin and V. Gallardo for inviting one of us (CN) to participate in the cruise Panorama Leg 3a aboard the $R / V$ Melville. Special thanks to J. Sellanes for valuable assistance on board and in the lab. We would like to thank Dr. T. Glatzel for kind help throughout SEM-microscopy process, and Drs. T. Höpner and K.-H. Schminke for laboratory facilities. Ship time was supported by the University of California. C. Neira was supported by the ICBM and the FONDAP-Humboldt Program.

\section{References}

Arntz WE, Tarazona J, Gallardo VA, Flores LA, Salzwedel H. 1991. Benthos communities in oxygen deficient shelf and upper slope areas of the Peruvian and Chilean Pacific coast, and changes caused by El Niño. In: Tyson, RV, Pearson, TH, eds. Modern and ancient Continental Shelf Anoxia. Geological Society Special Publication $N^{\circ} 58$. Tulsa Oklahoma, 131-154.

Bernhard JM, Buck KR, Farmer MA, Bowsers SS. 2000. The Santa Barbara Basin is a symbiosis oasis. Nature 403: 77-80.

Cook AA, Lambshead PJ, Hawkins LE, Mitchell N, Levin LA. 2000. Nematode abundance at the Oxygen Minimum Zone in the Arabian Sea. Deep-Sea Res. II 47: 75-85.

Diaz RJ, Rosenberg R. 1995. Marine benthic hypoxia, a review of its ecological effects and the behavioural responses of benthic macrofauna. Oceanogr. Mar. Biol. Ann. Rev. 33: 245-303.

Gooday AJ, Bernhard JM, Levin LA, Suhr S. 2000. Foraminifera in the Arabian Sea oxygen minimum zone and other oxygen deficient settings: taxonomic composition, diversity and relation to metazoan faunas. Deep-Sea Res. II 47: 25-54.
Gourbault N, Decraemer W. 1986. Nématodes maríns de Guadeloupe III. Epsilonematidae des genres nouveaux Metaglochinema n. g. (Glochinematinae) et Keratonema n. g. (Keratonematinae n. subfam.), Bull. Muss. nat. Hist. natur, Paris 4e série, 8, section A (1): 171-183.

Gourbault N, Decraemer W. 1993. New species of Glochinema and Metaglochinema (Nematoda, Epsilonematidae) from New Caledonia. Zool. Scripta 22: 223-227.

Gourbault N, Decraemer W. 1996. Marine nematodes of the family Epsilonematidae: a synthesis with phylogenetic relationships. Nematologica 42: 133-158.

Josefson AB, Widbom B. 1988. Differential response of benthic macrofauna and meiofauna to hypoxia in the Gullmar Fjord basin. Mar. Biol. 100: 31-40.

Kamykowski D, Zentara SJ. 1990. Hypoxia in the world ocean as recorded in the historical data set. Deep-Sea Res. I 37: 1861-1874.

Lamont PA, Gage JD 2000. Morphological responses of macrobenthic polychaetes to low oxygen on the Oman contínental slope, NW Arabían Sea. Deep-Sea Res, II 47: 9-24.

Levin LA, Huggett CL Wishner KF. 1991. Control of deepsea benthic community structure by oxygen and organicmatter gradients in the eastern Pacific Ocean. J. Mar. Res. 49: 763-800.

Levin LA, Gage JD, Martin C, Lamont PA. 2000. Macrobenthic community structure within and beneath the oxygen minimum zone, NW Arabian Sea. Deep-Sea Research II 47: 189-226.

Lorenzen, S. 1973. Die Familie Epsilonematidae (Nematodes). Mikrof. $d$. Meeresbod. 25: 1-86.

Lorenzen S. 1974. Glochinema nov. gen. (Nematodes, Epsilonematidae) aus Südchile. Mikrof. d. Meeresbod . 47: 393-412.

Moodley L, van der Zwaan GL, Herman GL, Breugel $P$. 1997. Differential response of benthic meiofauna to anoxia with special reference to foraminifera (Protista: Sarcodina). Mar. Ecol. Prog. Ser. 158: 151-163.

Morales C, Blanco J, Braun M, Reyes H, Silva N. 1996. Chlorophyll- $a$ distribution and associated oceanographic conditions in the upwelling region off northern Chile during the winter and spring 1993. Deep-Sea Res. 43: 267-289.

Neira C, Rackemann M. 1996. Black spots produced by buried macroalgae in intertidal sandy sediments of the Wadden Sea: effects on the meiobenthos. J. Sea Res. 36: 153-170.

Neira C, Sellanes J, Levin LA, Arntz WE. Meiofaunal distributions on the Peru margin: relationship to oxygen and organic matter availability. Deep-Sea Res. I (in press).

Rosenberg R, Arntz WE, Chumán de Flores E, Flores L.A, Carbajal G, Finger I, Tarazona J. 1983. Benthos biomass and oxygen deficiency in the Peruvian upwelling system. J. Mar. Res. 41: 263-279.

Rosenberg R, Hellman B, Johansson B. 1991. Hypoxic tolerance of marine benthic fauna. Mar. Ecol. Prog. Ser. 79: $127-131$. 
Sanders HL. 1969. Benthic marine diversity and the stability-time hypothesis. Brookhaven symposium in biology 12: 71-81.

Tarazona J, Arntz WE, Canahuire E. 1996. Impact of two ${ }_{2 E}$ El Niño" events of different intensity on the hypoxic soft bottom macrobenthos off the central Peruvian coast. P.S.Z.N.L. Mar. Ecol. 17: 425-446.

Tyson RV Pearson TH. 1991. Modern and ancient continental shelf anoxia, Vol. 58, London: Geological Society of London Special Publication, 1-24
Steiner G. 1927. Epsilonematidae, a new nemic family. $J$. Parasitol. 14: 65-66.

Walsh JJ. 1981. A carbon budget for overfishing off Peru. Nature 290: 300-304.

Wieser W. 1960. Benthic studies in Buzzards Bay. II. The meiofauna. Limnol. Oceanogr. 5: 121-137.

Wyrtki K. 1966. Oceanography of the eastern Pacific Ocean. Oceanogr. Mar. Biol. Ann. Rev. 4: 33-68.

Received: 4 November 2000 